\title{
Carbon Dioxide Adsorption by Calcium Zirconate at Higher Temperature
}

\author{
K.B. Kale, R.Y. Raskar, V.H. Rane, A.G. Gaikwad *) \\ CE \& PD Division, National Chemical Laboratory, Pune 411 008, India
}

Received: 23rd June 2012; Revised: 28th August 2012; Accepted: 30th August 2012

\begin{abstract}
The $\mathrm{CO}_{2}$ adsorption by calcium zirconate was explored at pre- and post- combustion temperature condition. The several samples of the calcium zirconate were prepared by different methods such as sol-gel, solid-solid fusion, template and micro-emulsion. The samples of the calcium zirconate were characterized by measurement of surface area, alkalinity/acidity, and recording the XRD patterns and SEM images. The $\mathrm{CO}_{2}$ adsorptions by samples of the calcium zirconate were studied in the temperature range 100 to $850{ }^{\circ} \mathrm{C}$ and the $\mathrm{CO}_{2}$ adsorptions were observed in the ranges of 6.88 to $40.6 \mathrm{wt} \%$ at $600{ }^{\circ} \mathrm{C}$ and 8 to $16.82 \mathrm{wt} \%$ at in between the temperatures 200 to $300{ }^{\circ} \mathrm{C}$. The effect of $\mathrm{Ca} / \mathrm{Zr}$ mol ratio in the samples of the calcium zirconate on the $\mathrm{CO}_{2}$ adsorption and alkalinity were discussed. The adsorbed moisture by the samples of the calcium zirconate was found to be useful for the $\mathrm{CO}_{2}$ adsorption. The promoted the samples of the calcium zirconate by $\mathrm{K}^{+}, \mathrm{Na}^{+}, \mathrm{Rb}^{+}, \mathrm{Cs}^{+}, \mathrm{Ag}^{+}$and $\mathrm{La}^{3+}$ showed the increased $\mathrm{CO}_{2}$ adsorption. The exposure time of $\mathrm{CO}_{2}$ on the samples of the calcium zirconate showed the increased $\mathrm{CO}_{2}$ adsorption. The samples of the calcium zirconate were found to be regenerable and reusable several times for the adsorption of $\mathrm{CO}_{2}$ for at the post- and pre-combustion temperature conditions. C 2012 BCREC UNDIP. All rights reserved
\end{abstract}

Keywords: Calcium zirconate; $\mathrm{CO}_{2}$ adsorption; effect of mol ratio; post- and pre-combustion temperature; sol-gel method

How to Cite: K.B. Kale, R.Y. Raskar, V.H. Rane, A.G. Gaikwad. (2012). Carbon Dioxide Adsorption by Calcium Zirconate at Higher Temperature. Bulletin of Chemical Reaction Engineering \& Catalysis, 7 (2): 124-136. (doi:10.9767/bcrec.7.2.3686.124-136)

Permalink/DOI: http://dx.doi.org/10.9767/bcrec.7.2.3686.124-136

\section{Introduction}

The carbon in the form of carbonate, hydrocarbons, and carbon dioxide, etc is found in the earth crust and atmosphere. However, carbonates and hydrocarbons are natural resources useful for the construction, chemical industry, fuel, etc. Trees are using large amount of $\mathrm{CO}_{2}$ from the atmosphere for their growth. However, the emitted $\mathrm{CO}_{2}$ from the outward sources such as vehicles, air craft's, thermal power station, animals, factories etc are the causes of surplus $\mathrm{CO}_{2}$ in the atmosphere. The surplus $\mathrm{CO}_{2}$ in the atmosphere causes the damage of biosphere by natural imbalance, global warming and air pollution. Therefore, there is a need to reduce the emission of $\mathrm{CO}_{2}$ in the atmosphere or to develop the technology to store the $\mathrm{CO}_{2}$ at the point of emission sources and then utilize it for development of value added products. The mixed metal oxides are emerged as the regenerable adsorbents for $\mathrm{CO}_{2}$ at higher temperature.

The emission of $\mathrm{CO}_{2}$ from the thermal power

* Corresponding Author.

E-mail: ag.gaikwad@ncl.res.in (A.G.Gaikwad) 
stations, vehicles, air craft's and industries are observed in the temperature ranges 100 to $450^{\circ} \mathrm{C}$ (post combustion conditions) and 450 to $850^{\circ} \mathrm{C}$ (precombustion conditions). The mixed metal oxides are suitable, stable and regenerable adsorbents for $\mathrm{CO}_{2}$ at conditions of post- and pre- combustion temperatures. Among the adsorbents, zeolite, amines and carbon are used for $\mathrm{CO}_{2}$ at low temperatures. However, these adsorbents lose their capacity for $\mathrm{CO}_{2}$ with increasing in temperature [1-2]. $\mathrm{MgO}$ and $\mathrm{CaO}$ are $\mathrm{CO}_{2}$ adsorbents at post- and pre- combustion temperatures; however, for achieving optimum $\mathrm{CO}_{2}$ adsorption capacity is required high energy consumption by increasing temperature to $1000{ }^{\circ} \mathrm{C}$ [3-8]. Recently, lithium zirconate, silicate, aluminate [9-12], magnesium silicate, zirconate and aluminate [13-16], calcium silicate and aluminate [17-20] and calcium zirconate [21-26] were emerged as the regenerable adsorbents for $\mathrm{CO}_{2}$ adsorption at low temperature. Mixed metal oxide catalysts are more favorable towards the hydrogenation of $\mathrm{CO}_{2}$ than adsorption. However, alkali and alkaline earth metal oxide containing mixed metal oxide are more favorable towards the $\mathrm{CO}_{2}$ adsorption. However, systematic investigations on $\mathrm{CO}_{2}$ adsorption by calcium zirconate are lacking. Therefore, in this paper, we report the preparation of several samples of the calcium zirconate by different methods such as solgel, solid-solid fusion, template and microemulsion; characterization of the samples of the calcium zirconate and screening of samples of the calcium zirconate for $\mathrm{CO}_{2}$ adsorption.

\section{Materials and Methods}

\subsection{Chemical and apparatus}

The chemicals calcium nitrate tetra hydrates, (S.D. Fine Chem. Pvt. Ltd), calcium carbonate, citric acid (Loba Cheme) were used to prepare calcium zirconate. All chemicals of analytical grade were used without any further purification. Carbon dioxide and helium of high purity were used (Deluxe India Ltd). A furnance (Thermax Co. Ltd) was used to calcine the calcium zirconate. A split furnace (Carbolite USA) was used to vary the temperature of the bed of the sample of the calcium zirconate adsorbent in the quartz reactor. The samples of the carbon dioxide were analyzed on line by using GC (Nucon India Ltd) with thermal conductivity detector.

\subsection{The samples of the calcium zirconate preparation}

The several samples of the calcium zirconate with variable $\mathrm{Ca} / \mathrm{Zr}$ mol ratios from 0.5 to 6 were prepared by different methods such as sol-gel, solid-solid fusion, template and micro emulsion, etc. The details of the preparation of samples of the calcium zirconate by different methods are given in the following sections.

\subsection{Preparation of samples of the calcium zirconate by sol-gel method}

The several samples of the calcium zirconate with different mol ratios of $\mathrm{Ca} / \mathrm{Zr}=0.5,1,2,3,4$ and 6 were prepared by sol gel method. Initially, for the preparation of samples of the calcium zirconate with $\mathrm{Ca} / \mathrm{Zr}=1 \mathrm{~mol}$ ratio, 0.0164, 0.0029 and 0.025 moles of citric acid, $\mathrm{Ca}\left(\mathrm{NO}_{3}\right)_{2} .4 \mathrm{H}_{2} \mathrm{O}$ and urea, respectively, were dissolved in $2.56 \mathrm{~mol}$ of deionized water in a glass reactor. Then, 0.00145 mol of zirconly nitrate was added in the above solution with constant stirring. The solution was kept under constant heating at $70{ }^{\circ} \mathrm{C}$ for $6 \mathrm{~h}$. After that, the reaction mixture was digested on water bath at $80{ }^{\circ} \mathrm{C}$ until the sol formation was completed. Then, the sol solution was thermally treated in a vaccum oven at $150{ }^{\circ} \mathrm{C}$ in order to remove the excess water and to obtain the solid mass. Further, the solid mass was calcined in the furnace in air at $900{ }^{\circ} \mathrm{C}$ for $3 \mathrm{~h}$ in order to obtain calcium zirconate crystalline phases. The particles of -22 to -30 mesh sizes were prepared from the calcined solid mass of the samples of the calcium zirconate.

\subsection{Preparation of samples of the calcium zirconate by solid-solid fusion method}

The samples of the calcium zirconate with different mol ratios of $\mathrm{Ca} / \mathrm{Zr}=0.5,1,2,3,4$ and 6 were prepared by solid-solid fusion method. The samples of the calcium zirconate with $\mathrm{Ca} / \mathrm{Zr}=1$ mol ratio were prepared by using 0.0058 and 0.023 moles of $\mathrm{CaCO}_{3}$ and $\mathrm{ZrO}\left(\mathrm{NO}_{3}\right)_{2}$, respectively. The solid masses of $\mathrm{CaCO}_{3}$ and $\mathrm{ZrO}\left(\mathrm{NO}_{3}\right)_{2}$ were thoroughly mixed together and then calcined at $900{ }^{\circ} \mathrm{C}$ for $3 \mathrm{~h}$ in air or helium atmosphere. The particles of -22 to -30 mesh sizes were prepared from the calcined solid mass of the samples of the calcium zirconate.

\subsection{Preparation of samples of the calcium zirconate by template method}

The different samples of the calcium zirconate with different moles ratios of $\mathrm{Ca} / \mathrm{Zr}=0.5,1,2,3,4$ and 6 were prepared by using CTAB (Cetyl tri methyl ammonium bromide) as a template. The samples of the calcium zirconate with $\mathrm{Ca} / \mathrm{Zr}=1$ mol ratio were prepared as follows. The solution A 
was prepared by dissolving $0.00611 \mathrm{~mol}$ of CATB in $1.09 \mathrm{~mol}$ of distilled water by addition of 0.0133 mol of $\mathrm{NaOH}$ in $0.34 \mathrm{~mol}$ of water. Then solution A was stirred for $1 \mathrm{~h}$ for getting clear homogeneous solution. The solution B was prepared by mixing 0.0115 mol of zirconium (IV) propoxide and 0.0015 mol of TMAOH (tetra methyl ammonium hydroxide) in $2.78 \mathrm{~mol}$ of water by constant stirring. Then, solution A was added into the solution B by stirring. In the mixture of solutions, $0.027 \mathrm{~mol}$ of $\mathrm{CaCO}_{3}$ was added as calcium precursor. The solution mixture was aged for $24 \mathrm{~h}$ in order to complete the precipitation. Then, the solid mass was separated by filtration from the solution mixture. The separated solid mass was washed with distilled water in order to remove the dissolved and unwanted material. Further, the solid mass was dried in an oven at $100{ }^{\circ} \mathrm{C}$ for $6 \mathrm{~h}$. Then, the dried mass was calcined in a furnace in air at $900{ }^{\circ} \mathrm{C}$ for $3 \mathrm{~h}$. The particles of -22 to -30 mesh sizes were prepared from the calcined solid mass. The different samples of the calcium zirconate with different moles ratios of $\mathrm{Ca} / \mathrm{Zr}$ were prepared by varying the quantity of zirconium (IV) propoxide. However, the mol ratio of $\mathrm{Ca} / \mathrm{Zr}$ in the calcined mass of the samples of the calcium zirconate was determined by EDAX analysis for the $\mathrm{Ca} / \mathrm{Zr}$ mol ratio confirmation.

\subsection{Preparation of samples of the calcium zirconate by micro emulsion method}

The some samples of the calcium zirconate of different $\mathrm{Ca} / \mathrm{Zr}=0.5,1,2,3,4$ and 6 moles ratios were prepared by using micro emulsion method. The solution A was prepared by stirring and adding the $0.61 \mathrm{~mol}$ of cyclohexane as the oil phase, $0.035 \mathrm{~mol}$ of Triton X - 100 as surfactant, $0.107 \mathrm{~mol}$ of $n$-hexanol as co-surfactant in 0.035 mol of water. Solution B was prepared by adding and stirring the zirconium (IV) propoxide and calcium hydroxide in $0.5 \mathrm{M}$ ammonium hydroxide. For the preparation of samples of the calcium zirconate of $\mathrm{Ca} / \mathrm{Zr}=1 \mathrm{~mol}$ ratio, $0.04 \mathrm{~mol}$ each of calcium hydroxide and zirconium (IV) propoxide were used. The solution A and B were slowly mixed together with constant stirring. After aging this reaction mixture for two hours, the precipitated solid mass was separated by centrifugation. The solid mass was washed with acetone and then solid mass was dried in an oven at $110^{\circ} \mathrm{C}$ for $10-12 \mathrm{~h}$. The dried solid mass was calcined in a furnace in the air at $900{ }^{\circ} \mathrm{C}$ for $3 \mathrm{~h}$. However, for the preparation of samples of the calcium zirconate of different $\mathrm{Ca} / \mathrm{Zr}$ mol ratios, zirconium (IV) propoxide moles were varied. The particles of -22 to -30 mesh sizes were prepared from the calcined solid mass of the sample of the calcium zirconate.

\subsection{Procedure for $\mathrm{CO}_{2}$ adsorption by the samples of the calcium zirconate}

The procedure for carbon dioxide adsorption was evolved with the designed set up with the gaseous connections. The gaseous connection set up was designed by using $4 \mathrm{~mm}$ od stainless steel tubing, four three ways valves, gas sampling valve, carbolite split furnace with temperature controller, a quartz reactor, Nucon GC and flow control valves as described in the Figure 1. During the adsorption process of $\mathrm{CO}_{2}$, the flows of helium and carbon dioxide were changed with four three way valves as needed for the flushing and adsorption. A quartz tube reactor was fabricated from a quartz tube with the dimensions of $6 \mathrm{~mm}$ od, $4 \mathrm{~mm}$ id and 850 $\mathrm{mm}$ length. The quartz tube reactor at the centre was designed of the dimensions of 10 to $20 \mathrm{~mm}$ id and $100 \mathrm{~mm}$ length with a quartz tube. The sample of the adsorbent was placed inside at the center of the quartz tube reactor with the support of quartz wool. The temperature of the bed of the sample of the adsorbent was maintained by setting the quartz reactor inside the split furnace with the gaseous connections. The quartz reactor was connected by stainless tubing and connectors through four three ways valves and a sampling valve to GC. The 0.01 to $0.25 \mathrm{~g}$ amount of bed of the sample of the adsorbent with the particle size 22 to -30 meshes was used at the center of the quartz tube reactor for $\mathrm{CO}_{2}$ adsorption. The temperature of a split furnace with quartz reactor was controlled by a programmed temperature controller. The temperature of the bed of the sample of the adsorbent was recorded by using a

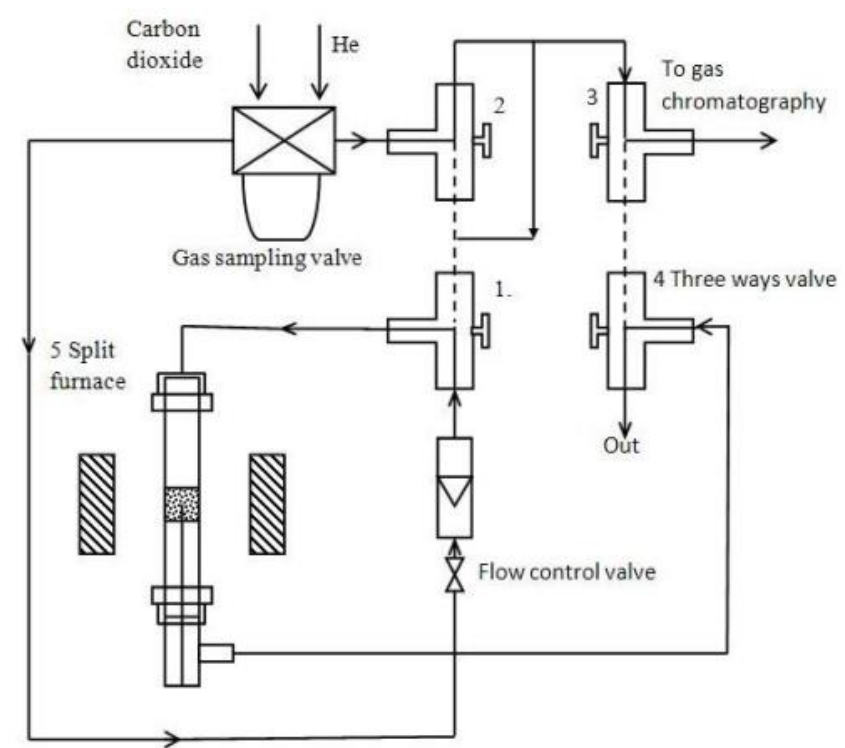

Figure 1. The designed schematic set up for the carbon dioxide adsorption 
thermocouple and digital temperature indicator. First, the bed of the sample of the adsorbent was flushed with helium gas in order to remove the stresses of the impurity gases from the bed of the sample of the adsorbent, gaseous connections and quartz reactor. Then, the bed of the sample of the adsorbent was flushed with $\mathrm{CO}_{2}$ to remove the free helium gas. After that, the carbon dioxide was allowed to adsorb over the bed of the sample of the adsorbent at a certain pressure, temperature and time in the absence of helium gas. The adsorbed carbon dioxide by the bed of the sample of the adsorbent was removed by using the helium as a carrier gas and increasing the temperature of the quartz reactor containing the bed of the sample of the adsorbent. The removed carbon dioxide was estimated by GC using a Porapak-Q column and thermal conductivity detector. The analyzed carbon dioxide was expressed as adsorbed $\mathrm{CO}_{2}$ in wt\% by the sample of the adsorbent of calcium zirconate at STP.

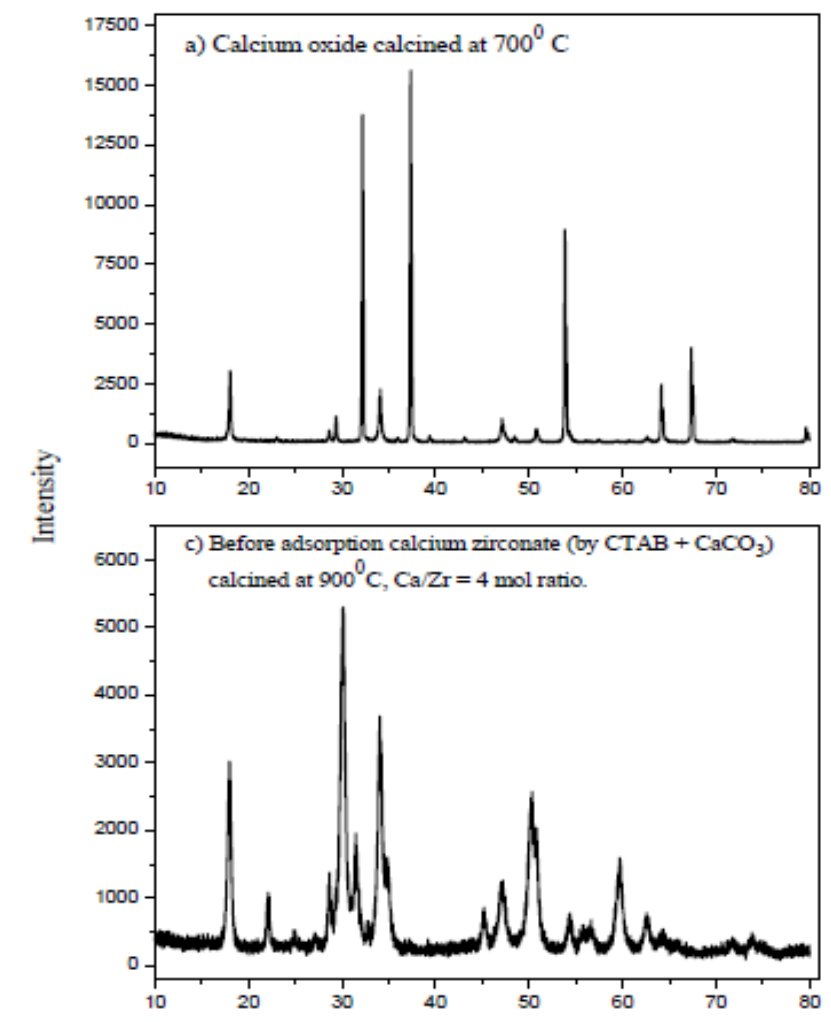

\subsection{Characterization of the samples of the calcium zirconate}

The samples of the calcium zirconate adsorbent were characterized by the acid-base titrations for alkalinity/acidity, by X-ray diffraction (Philips Power XRD) for XRD patterns, for surface area by surface analyzer (Model Autosorb-1, MakeQuanta chrome Instruments Pvt. LTD, USA) and SEM images (QUANTA 200 3D). The samples of the calcium zirconate prepared by sol gel, solidsolid fusion template and micro emulsion methods were selected for the characterization.

\section{Results and Discussion}

\subsection{Mechanism of $\mathrm{CO}_{2}$ adsorption by the samples of the calcium zirconate}

The $\mathrm{CO}_{2}$ reacts with the samples of the calcium and zirconium oxide to form the carbonates at higher temperature. The reactions of formation of

$$
\begin{aligned}
& \mathrm{xCaO}+\mathrm{y} \mathrm{ZrO}_{2} \leftrightarrow \mathrm{Ca}_{\mathrm{x}} \mathrm{Zr}_{\mathrm{y}} \mathrm{O}_{(\mathrm{x}+2 \mathrm{y})} \\
& \mathrm{Ca}_{\mathrm{x}} \mathrm{Zr}_{\mathrm{y}} \mathrm{O}_{(\mathrm{x}+2 \mathrm{y})}+(\mathrm{x}+\mathrm{y}) \mathrm{CO}_{2} \leftrightarrow \mathrm{xCaCO}_{3}+\mathrm{y} \mathrm{ZrOCO}_{3}
\end{aligned}
$$
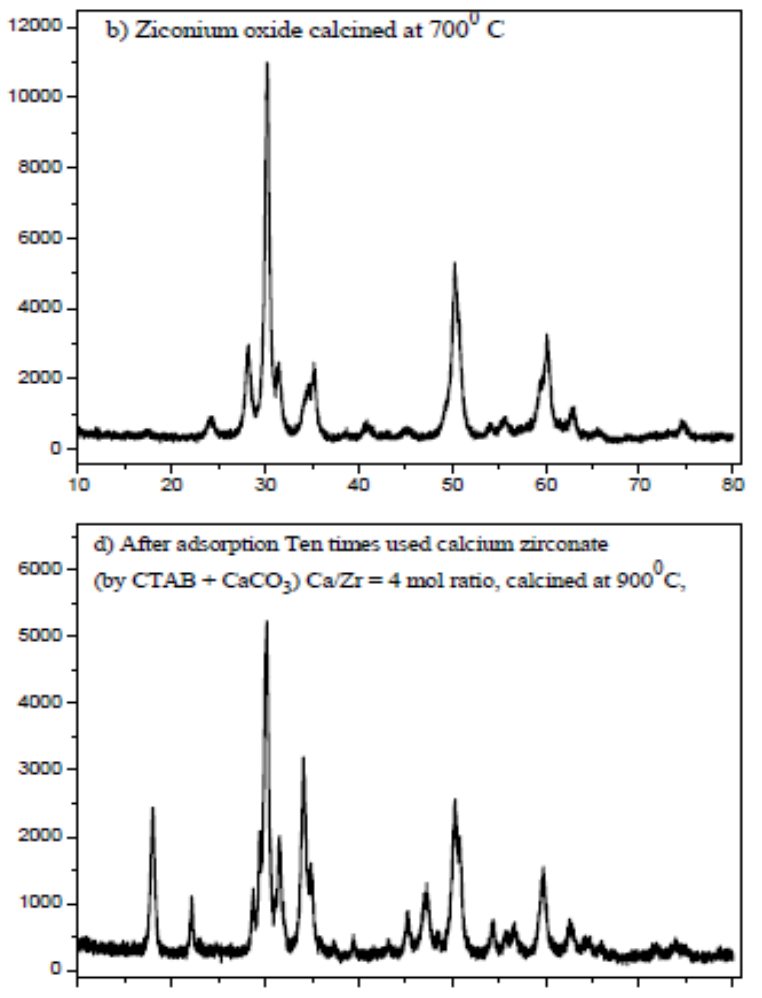

Two Theta( $)$

Figure 2. XRD pattern of (a) the sample of the calcium oxide, (b) sample of the zirconium oxide, (c) the sample of the calcium zirconate before the $\mathrm{CO}_{2}$ adsorption and the sample of the calcium zirconate was prepared by template CTAB + $\mathrm{CaCO}_{3}$ method, (d) the sample of the calcium zirconate after ten times was used to $\mathrm{CO}_{2}$ adsorption and the sample of the calcium zirconate was prepared by the template $\mathrm{CTAB}+$ precursor $\mathrm{CaCO}_{3}$ and calcined at $900{ }^{\circ} \mathrm{C}$ for $3 \mathrm{~h}$. 
calcium zirconate, calcium and zirconium carbonates are given by the following equations. In which the $\mathrm{x}$ and $\mathrm{y}$ represent the mol fractions of the calcium and zirconium, respectively. Calcium carbonate is stable however, zirconium carbonate is meta-stable.

\subsection{Characterization of the samples of the calcium zirconate}

The samples of the calcium zirconate were characterized by using surface area, alkalinity/acidity, SEM images and XRD patterns. In the Figures $2 \mathrm{a}$ and $2 \mathrm{~b}$, the XRD patterns were shown of the samples of the calcium zirconate before the $\mathrm{CO}_{2}$ adsorption. Where, the samples of the calcium zirconate were prepared by the solidsolid fusion method by using the calcium and zirconyl nitrates precursors. The samples of the calcium zirconate were calcined at $900{ }^{\circ} \mathrm{C}$ for $3 \mathrm{~h}$.
In the XRD patterns of the samples of the calcium zirconate, the calcium oxide, zirconium oxide and calcium zirconate phases were observed. In the Figure 2 (c), the XRD patterns of the samples of the calcium zirconate were shown. In this case, the samples of the calcium zirconate were prepared by using the template $\mathrm{CTAB}$ and precursor $\mathrm{CaCO}_{3}$. The samples of the calcium zirconate were used for the $\mathrm{CO}_{2}$ adsorption and then the XRD patterns of the samples of the calcium zirconate were recorded. The XRD patterns of the samples of the calcium zirconate show the crystalline phases of $\mathrm{CaO}, \quad \mathrm{ZrO}_{2}$ and $\mathrm{CaZrO}_{3}$. The observed XRD patterns of the samples of the calcium zirconate indicate that the calcium zirconate phase was regenerated. In the Figure 2 d, XRD patterns of the samples of the calcium zirconate show the crystalline phases of $\mathrm{CaO}, \mathrm{ZrO}_{2}$ and $\mathrm{CaZrO}_{3}$. Where, the samples of the calcium zirconate were used for $\mathrm{CO}_{2}$ adsorption for ten times after the $\mathrm{CO}_{2}$
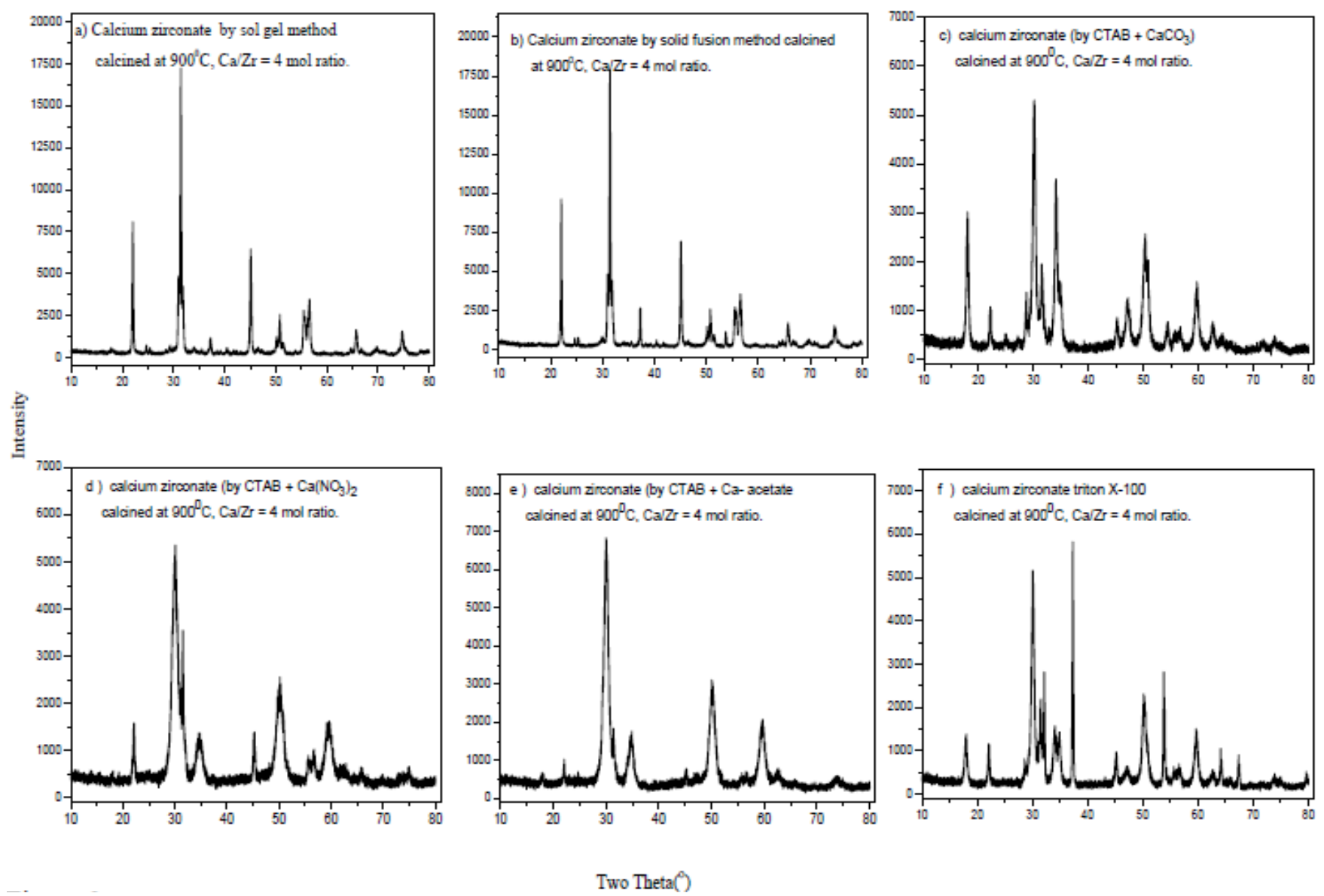

Figure 3. XRD pattern of (a) the sample of the calcium zirconate was prepared by sol gel method, (b) the sample of the calcium zirconate was prepared by solid- solid fusion method, (c) the sample of the calcium zirconate was prepared by $\mathrm{CTAB}+\mathrm{CaCO}_{3}$ method, (d) the sample of the calcium zirconate was prepared by template $\mathrm{CTAB}+\mathrm{Ca}\left(\mathrm{NO}_{3}\right)_{2}$ method, (e) the sample of the calcium zirconate was prepared by template $\mathrm{CTAB}+\mathrm{Ca}$ - acetate method and (f) the sample of the calcium zirconate was prepared by template triton $\mathrm{X}-100$ method. 
desorption. The results of characterization of the samples of the calcium zirconate by XRD pattern show that the calcium zirconate phase was regenerated during the process of $\mathrm{CO}_{2}$ adsorption and desorption.

Figure 3 shows the XRD patterns of the samples of the calcium zirconate. In the Figure $3 \mathrm{a}$, the XRD patterns of the samples of the calcium zirconate were shown for the sample of calcium zirconate with $\mathrm{Ca} / \mathrm{Zr}=4 \mathrm{~mol}$ ratio. The samples of the calcium zirconate were prepared by the sol-gel method by using the precursor calcium and zirconyl nitrate and then samples of the calcium zirconate were calcined in air for $3 \mathrm{~h}$ at $900{ }^{\circ} \mathrm{C}$. The $\mathrm{CaZrO}_{3}$ and $\mathrm{CaO}$ phases were observed in the samples of the calcium zirconate. In the Figure $3 \mathrm{~b}$, the XRD patterns were shown of the samples of the calcium zirconate with $\mathrm{Ca} / \mathrm{Zr}=4 \mathrm{~mol}$ ratio. The samples of the calcium zirconate were prepared by solid-solid fusion method by using the precursors $\mathrm{CaCO}_{3}$ and zirconyl nitrate and then the samples of the calcium zirconate were calcined in air at $900{ }^{\circ} \mathrm{C}$ for $3 \mathrm{~h}$. In the Figure $3 \mathrm{c}$, XRD patterns of the samples of the calcium zirconat were shown. The samples of the calcium zirconate were prepared by using the template CTAB and precursor $\mathrm{CaCO}_{3}$. The crystalline phase of $\mathrm{CaO}$ was observed at $35^{\circ}$ in the samples of the calcium zirconate (Figure c). In the Figure $3 \mathrm{~d}$ and $3 \mathrm{e}$, the XRD patterns of the samples of the calcium zirconate were shown. The samples of the calcium zirconate were prepared by using the template CTAB and precursors $\mathrm{Ca}\left(\mathrm{NO}_{3}\right)_{2}$ (Figure $3 \mathrm{~d}$ ) and calcium acetate (Figure $3 \mathrm{e}$ ). The $\mathrm{CaO}$ phase at $35^{\circ}$ was not observed in the XRD patterns of the samples of the calcium zirconate indicating that the calcium zirconate phase was dominantly formed and observed in the samples of the calcium zirconate.

In the Table 1, the surface areas of the samples of the calcium oxide, zirconium oxide, alumina and silica were given. The samples of the calcium zirconate are very low surface area; however, the $\mathrm{CO}_{2}$ reactions with the samples of the calcium zirconate are governed by the Equations 1 and 2 which reactions are the calcium and zirconium carbonate formation. Where, the samples of the calcium oxide were prepared by calcining calcium nitrate at $900{ }^{\circ} \mathrm{C}$ for $3 \mathrm{~h}$, the samples of the

Table 1. The surface area, alkalinity/ acidity of the samples of the calcium zirconate, and the $\mathrm{CO}_{2}$ adsorption by the samples of the calcium zirconate

\begin{tabular}{|c|c|c|c|c|}
\hline Sr. No & $\begin{array}{l}\text { Calcium zirconate, } \\
\mathrm{Ca} / \mathrm{Zr} \text { mol ratio }\end{array}$ & $\begin{array}{l}\text { Alkalinity, } \\
\text { mmol g-1 }\end{array}$ & Surface area, $\mathrm{m}^{2} \mathrm{~g}^{-1}$ & $\begin{array}{l}\mathrm{CO}_{2} \text { adsorption } \\
\text { at } 600^{\circ} \mathrm{C} \text {, wt \% }\end{array}$ \\
\hline 1 & $\mathrm{CaO}$ & 20.0 & 9.37 & 6.88 \\
\hline 2 & $\mathrm{ZrO}_{2}$ & $\begin{array}{c}0.56 \\
\text { (Acidity) }\end{array}$ & 81.97 & 8.39 \\
\hline 3 & $\mathrm{SiO}_{2}$ & $\begin{array}{c}1.1 \\
\text { (Acidity) }\end{array}$ & 236.39 & 1.10 \\
\hline \multirow[t]{2}{*}{4} & $\mathrm{Al}_{2} \mathrm{O}_{3}$ & 2.4 & 67.56 & 12.24 \\
\hline & Sol-gel method & & & \\
\hline 5 & $\begin{array}{l}\text { The sample of calcium zirconate }(\mathrm{Ca} / \mathrm{Zr}=4 \mathrm{~mol} \\
\text { ratio) calcined in the air } 900^{\circ} \mathrm{C} \text { for the } 3 \mathrm{~h}\end{array}$ & 3 & 2.25 & 18 \\
\hline \multirow[t]{2}{*}{6} & $\begin{array}{l}\text { Solid-solid fusion method } \\
\text { The sample of } \mathrm{CaCO}_{3} \text { and } \mathrm{ZrO}\left(\mathrm{NO}_{3}\right)_{2}(\mathrm{Ca} / \mathrm{Si}=4 \mathrm{~mol} \\
\text { ratio) calcined in the air for the } 3 \mathrm{~h}\end{array}$ & 5 & & 19.61 \\
\hline & Template method & & & \\
\hline 7 & $\begin{array}{l}\text { The sample of calcium zirconate with CTAB }+ \\
\mathrm{NaOH}+\mathrm{TMAOH}+\mathrm{CaCO}_{3}+\mathrm{ZrO}\left(\mathrm{NO}_{3}\right)_{2}(\mathrm{Ca} / \mathrm{Zr}=4 \\
\text { mol ratio initial }) \text { calcined in the air for the } 3 \mathrm{~h}\end{array}$ & 11.8 & 11.84 & 23.39 \\
\hline 8 & $\begin{array}{l}\text { The sample of calcium zirconate with }(\mathrm{CTAB})+ \\
\mathrm{NaOH}+\mathrm{TMAOH}+\mathrm{Ca}\left(\mathrm{NO}_{3}\right)_{2}+\mathrm{ZrO}\left(\mathrm{NO}_{3}\right)_{2}(\mathrm{Ca} / \mathrm{Zr}= \\
4 \mathrm{~mol} \text { ratio initial }) \text { calcined in the air for the } 3 \mathrm{~h}\end{array}$ & 1.2 & 15.35 & 15.92 \\
\hline 9 & $\begin{array}{l}\text { The sample of calcium zirconate with }(\mathrm{CTAB})+ \\
\mathrm{NaOH}+\mathrm{TMAOH}+\mathrm{Calcium} \text { acetate }+\mathrm{ZrO}\left(\mathrm{NO}_{3}\right)_{2} \\
(\mathrm{Ca} / \mathrm{Zr}=4 \mathrm{~mol} \text { ratio initial) calcined in the air for } \\
\text { the } 3 \mathrm{~h}\end{array}$ & 1.5 & 11.71 & 17.32 \\
\hline 10 & $\begin{array}{l}\text { Micro emulsion method } \\
\text { The sample of calcium zirconate with cyclohexane } \\
+ \text { Triton } \mathrm{X}-100+n \text {-hexanol }+ \text { calcium hydroxide }+ \\
\text { zirconium (IV) propoxide }(\mathrm{Ca} / \mathrm{Si}=4 \mathrm{~mol} \text { ratio ini- } \\
\text { tial) calcined in the air for the } 3 \mathrm{~h}\end{array}$ & 19.6 & 3.19 & 24.81 \\
\hline
\end{tabular}


zirconium oxide were prepared by calcining zirconly nitrate at $900{ }^{\circ} \mathrm{C}$ for $3 \mathrm{~h}$, the samples of the fumed silica (Aldrich) were used, and the samples of the alumina were prepared by calcining aluminium hydroxide at $900{ }^{\circ} \mathrm{C}$ for $3 \mathrm{~h}$. The surface areas of the samples of the calcium oxide, zirconium oxide, alumina and silica were 9.37, 81.97, 236.39 and $67.56 \mathrm{~m}^{2} \mathrm{~g}^{-1}$, respectively. The surface areas of the samples of the calcium zirconate prepared by different methods such as sol-gel (by using precursors $\mathrm{Ca}\left(\mathrm{NO}_{3}\right)_{2}$ and $\mathrm{ZrO}\left(\mathrm{NO}_{3}\right)_{2}$ with $\mathrm{Ca} / \mathrm{Zr}=4 \mathrm{~mol}$ ratio and calcined at $900{ }^{\circ} \mathrm{C}$ for $3 \mathrm{~h}$ ), solid-solid fusion (by using precursors $\mathrm{CaCO}_{3}$ and $\mathrm{ZrO}\left(\mathrm{NO}_{3}\right)_{2}$ of $\mathrm{Ca} / \mathrm{Zr}=4 \mathrm{~mol}$ ratio and calcined at $900{ }^{\circ} \mathrm{C}$ for $3 \mathrm{~h}$ ), template method (by using precursors $\mathrm{CTAB}$ and $\mathrm{ZrO}\left(\mathrm{NO}_{3}\right)_{2}$ of $\mathrm{Ca} / \mathrm{Zr}=4 \mathrm{~mol}$ ratio and also using precursors $\mathrm{CTAB}$ and calcium acetate of $\mathrm{Ca} / \mathrm{Zr}=4 \mathrm{~mol}$ ratio and calcined at $900{ }^{\circ} \mathrm{C}$ for $3 \mathrm{~h}$ ), micro emulsion (by
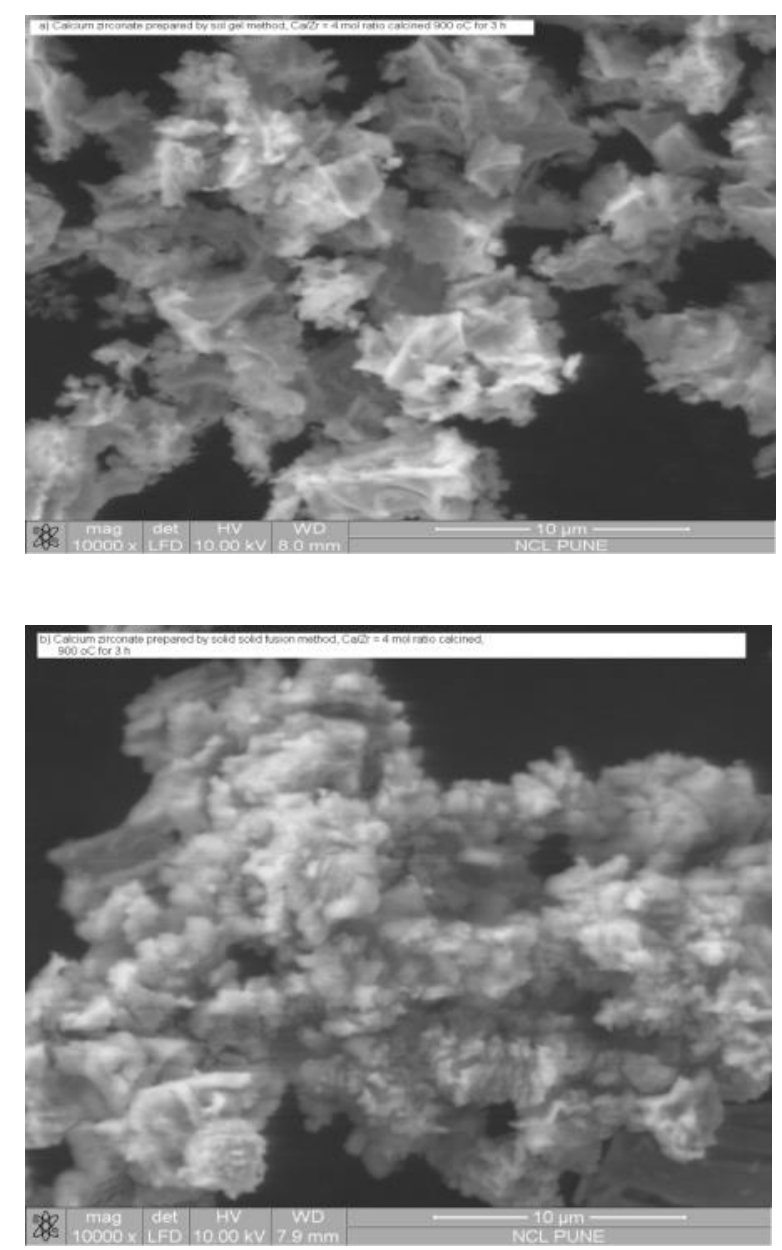

using the precursors $\mathrm{Ca}(\mathrm{OH})_{2}$ and $\mathrm{ZrO}\left(\mathrm{NO}_{3}\right)_{2}$ and calcined at $900{ }^{\circ} \mathrm{C}$ for $3 \mathrm{~h}$ ) were observed $2.5,10.50$, $11.84,15.35,11.71$ and $3.29 \mathrm{~m}^{2} \mathrm{~g}^{-1}$, respectively (Table 1). The observed surface areas of the samples of the calcium zirconate were low. The $\mathrm{CO}_{2}$ adsorption could be mainly due to the calcium and zirconium carbonate formation in the samples of the calcium zirconate at higher temperature.

In the Figures 4 a-d, the selected SEM images of the samples of the calcium zirconate were given. Where, the samples of the calcium zirconates were prepared by different methods such as sol-gel (by using precursors $\mathrm{Ca}\left(\mathrm{NO}_{3}\right)_{2}$ and $\mathrm{ZrO}\left(\mathrm{NO}_{3}\right)_{2}$ of $\mathrm{Ca} / \mathrm{Zr}$ $=4 \mathrm{~mol}$ ratio), solid-solid fusion (by using the precursors $\mathrm{CaCO}_{3}$ and $\mathrm{ZrO}\left(\mathrm{NO}_{3}\right)_{2}$ of $\mathrm{Ca} / \mathrm{Zr}=4 \mathrm{~mol}$ ratio), template (by using precursors $\mathrm{CaCO}_{3}, \mathrm{CTAB}$ and $\mathrm{ZrO}\left(\mathrm{NO}_{3}\right)_{2}$ of $\mathrm{Ca} / \mathrm{Zr}=4 \mathrm{~mol}$ ratio), and micro emulsion (by using precursors $\mathrm{Ca}(\mathrm{HO})_{2}$ and $\left.\mathrm{ZrO}\left(\mathrm{NO}_{3}\right)_{2}\right)$ methods. The SEM images show the
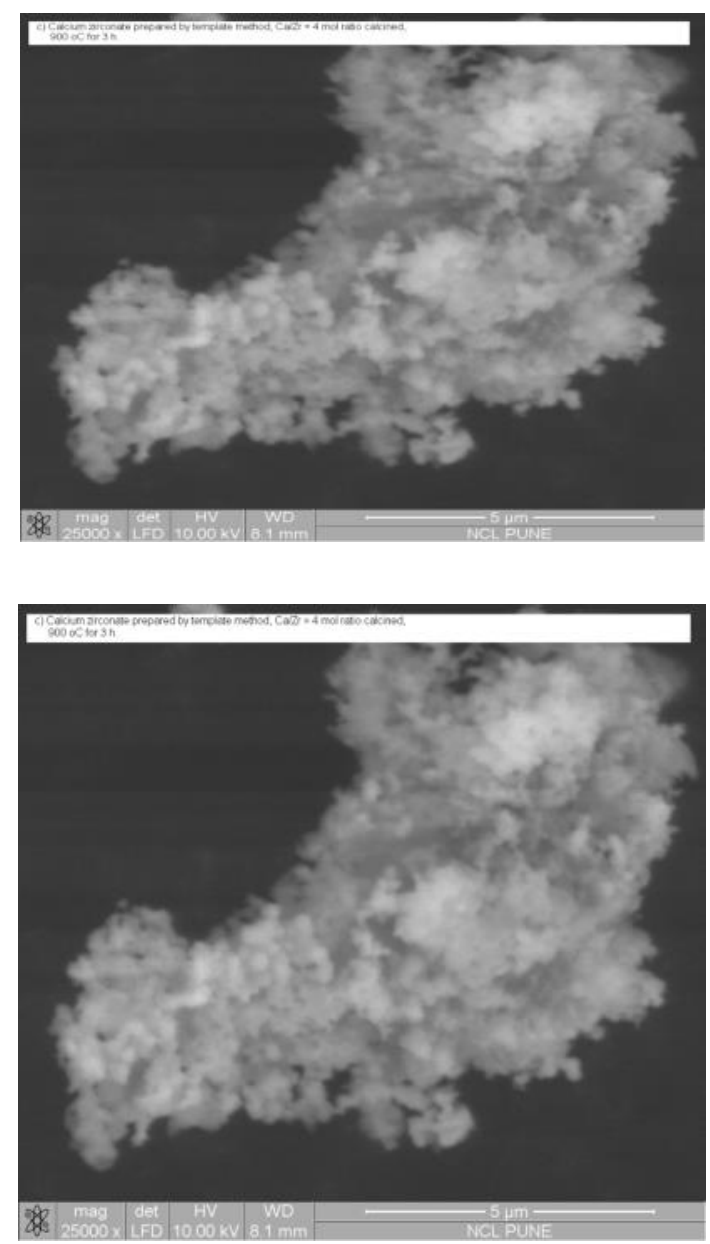

Figure 4. SEM images of (a) the sample of the calcium zirconate was prepared by sol gel method (Ca/Zr= $4 \mathrm{~mol}$ ratio) and calcined at $900{ }^{\circ} \mathrm{C}$ for $3 \mathrm{~h}$, (b) the sample of the calcium zirconate was prepared by solidsolid fusion method ( $\mathrm{Ca} / \mathrm{Zr}=4 \mathrm{~mol}$ ratio) and calcined at $900{ }^{\circ} \mathrm{C}$ for $3 \mathrm{~h}$, (c) the sample of the calcium zirconate was prepared by template method $\left(\mathrm{Ca} / \mathrm{Zr}=4 \mathrm{~mol}\right.$ ratio) and calcined at $900{ }^{\circ} \mathrm{C}$ for $3 \mathrm{~h}$ and (d) the sample of the calcium zirconate was prepared by micro emulsion method $(\mathrm{Ca} / \mathrm{Zr}=4 \mathrm{~mol}$ ratio) and calcined at $900{ }^{\circ} \mathrm{C}$ for $3 \mathrm{~h}$. 
crystalline particles of the calcium zirconate, calcium and zirconium oxides in the samples of calcium zirconate.

\subsection{Themo-gravimetric analysis of the samples of calcium zirconate}

The thermo-gravimetric analysis was done in order to check the loss in weight and also moisture content in the samples of calcium zirconate (calcined the calcium zirconate at $900{ }^{\circ} \mathrm{C}$ for $3 \mathrm{~h}$ ). In the Figure 5, thermo-gravimetric curve was shown for the samples of calcium zirconate. The samples of calcium zirconate with $\mathrm{Ca} / \mathrm{Zr}=4 \mathrm{~mol}$ ratio were

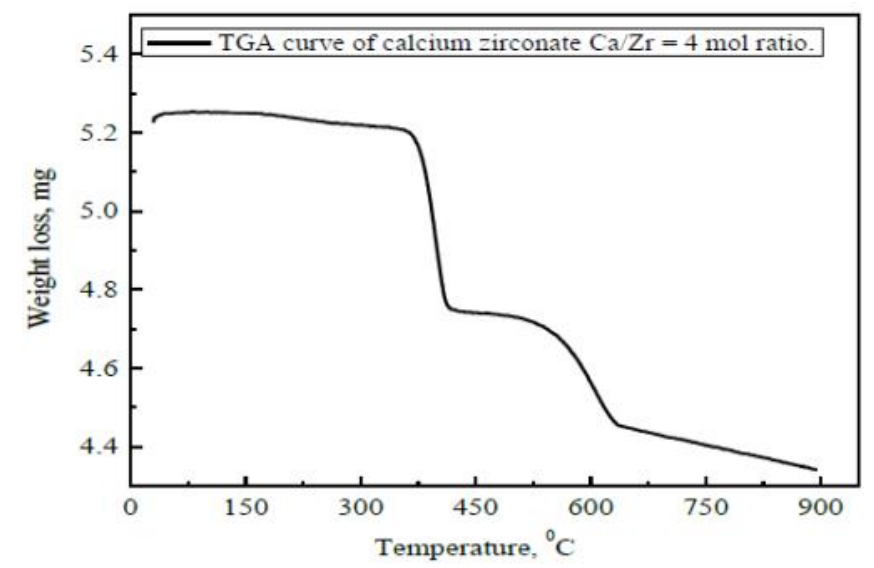

Figure 5. Thermo-gravimetric analysis of the sample of the calcium zirconate of $\mathrm{Ca} / \mathrm{Zr}=4 \mathrm{~mol}$ ratio was prepared by using template $\mathrm{CTAB}$ and $\mathrm{CaCO}_{3}$

prepared by using the template CTAB and precursor $\mathrm{CaCO}_{3}$. The estimated loss in weight in the samples of the calcium zirconate was $16.97 \mathrm{wt}$ $\%$ for the studied temperature range from 40 to 900 ${ }^{\circ} \mathrm{C}$. The loss in weight in the samples of the calcium zirconate was due to the loss of moisture from the samples of the calcium zirconate. However, the presence of moisture in the samples of the calcium zirconate also helps for the adsorption of $\mathrm{CO}_{2}$.

\subsection{Temperature profile of carbon dioxide adsorption by the samples of the calcium zirconate}

The $\mathrm{CO}_{2}$ adsorptions at $600{ }^{\circ} \mathrm{C}$ by samples of $\mathrm{CaO}, \mathrm{ZrO}_{2}, \mathrm{SiO}_{2}$ and alumina observed were 6.88 , 8.39, 1.1 and $12.24 \mathrm{wt} \%$, respectively, (Table 1). In the Figure 6 , the $\mathrm{CO}_{2}$ adsorption in wt $\%$ by the sample of calcium zirconate with $\mathrm{Ca} / \mathrm{Zr}=4 \mathrm{~mol}$ ratio was shown for the temperature range from 100 to $850^{\circ} \mathrm{C}$. The samples of the calcium zirconate were prepared by the sol gel, solid-solid fusion, template and micro emulsion methods. Then, these samples of calcium zirconate were calcined at 900 ${ }^{\circ} \mathrm{C}$ in air for $3 \mathrm{~h}$. The $\mathrm{CO}_{2}$ adsorption in wt\% by sample of calcium zirconate was observed in two major temperature chromatogram zones from 100 to $400{ }^{\circ} \mathrm{C}$ and 400 to $850{ }^{\circ} \mathrm{C}$. The first 100 to 400 ${ }^{\circ} \mathrm{C}$ temperature chromatogram zone of $\mathrm{CO}_{2}$ adsorption by sample of calcium zirconate was shown the $\mathrm{CO}_{2}$ adsorption 7 to $17 \mathrm{wt} \%$. This first 100 to $400{ }^{\circ} \mathrm{C}$ temperature chromatogram zone represents the post-combustion temperature. However, the second 400 to $850{ }^{\circ} \mathrm{C}$ temperature chromatogram zone of $\mathrm{CO}_{2}$ adsorption by sample of calcium zirconate was shown the $\mathrm{CO}_{2}$ adsorption in the range 15 to $25 \mathrm{wt} \%$. This second 400 to $850{ }^{\circ} \mathrm{C}$ temperature chromatogram zone represents the pre-combustion temperature. The $\mathrm{CO}_{2}$ adsorption by the sample of calcium zirconate was highest at $600{ }^{\circ} \mathrm{C}$. The $\mathrm{CO}_{2}$ adsorption by the sample of calcium zirconate prepared by sol gel method with $\mathrm{Ca} / \mathrm{Zr}=4 \mathrm{~mol}$ ratio and calcined in helium at 900 ${ }^{\circ} \mathrm{C}$ was shown $18 \mathrm{wt} \%$ at $600{ }^{\circ} \mathrm{C}$. However, the $\mathrm{CO}_{2}$ adsorptions at $600{ }^{\circ} \mathrm{C}$ by the samples of calcium zirconate were 19.61, 23.39 and $24.84 \mathrm{wt} \%$, respectively, when the sample of calcium zirconate with $\mathrm{Ca} / \mathrm{Zr}=4 \mathrm{~mol}$ ratio were prepared by different methods such as solid-solid fusion, template and micro emulsion methods. Then, these samples of calcium zirconates were calcined in air at $900{ }^{\circ} \mathrm{C}$ for $3 \mathrm{~h}$. The $\mathrm{CO}_{2}$ adsorption at $600{ }^{\circ} \mathrm{C}$ by the sample of calcium zirconate was higher than that of the $\mathrm{CO}_{2}$ adsorption by the samples of $\mathrm{CaO}$ and $\mathrm{ZrO}_{2}$.

\section{5. $\mathrm{CO}_{2}$ adsorption at $600{ }^{\circ} \mathrm{C}$ by the samples of calcium zirconate (sol-gel method)}

In order to assess the role of $\mathrm{Ca} / \mathrm{Zr}$ mol ratio in

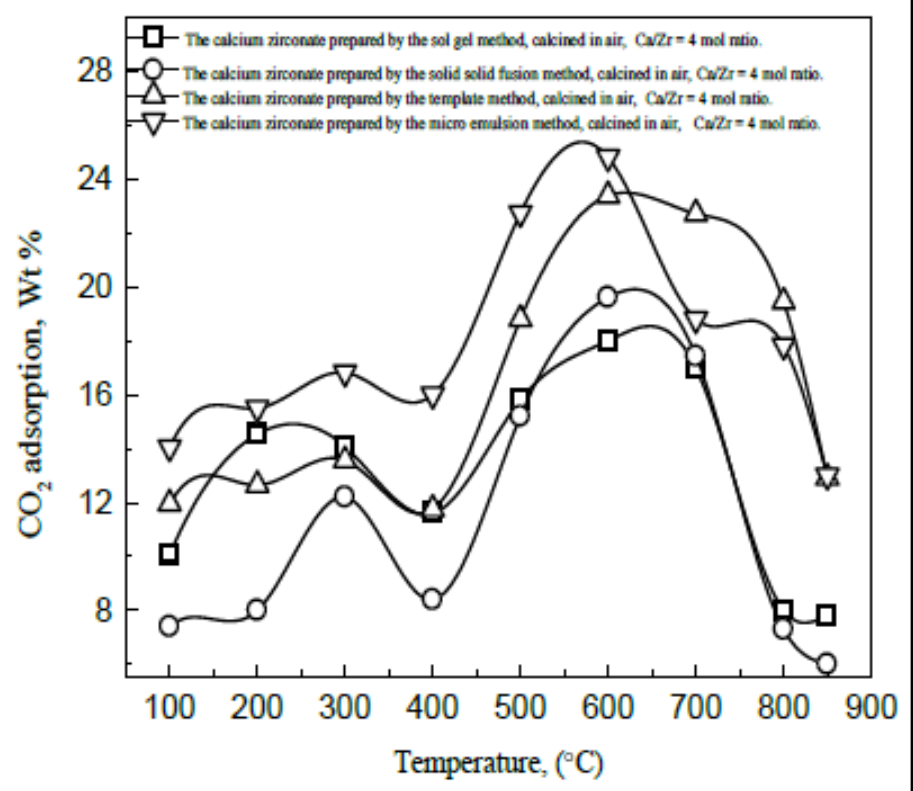

Figure 6. Temperature profile of the carbon dioxide adsorption by the sample of the calcium zirconate where the samples of the calcium zirconate were prepared by different methods. 
the $\mathrm{CO}_{2}$ adsorption by the sample of calcium zirconate at $600{ }^{\circ} \mathrm{C}$, the several samples of calcium zirconate with $\mathrm{Ca} / \mathrm{Zr}=0.5$ to $6 \mathrm{~mol}$ ratios were prepared by the sol-gel method (Figure 7). Then, these samples of calcium zirconate were calcined at $900{ }^{\circ} \mathrm{C}$ for $3 \mathrm{~h}$ in air. The alkalinity of the samples of calcium zirconate and $\mathrm{CO}_{2}$ adsorption by the samples of calcium zirconate with $\mathrm{Ca} / \mathrm{Zr}=0.5$ to 6 mol ratios were observed in the range from 0.2 to $9.4 \mathrm{mmol} \mathrm{g}^{-1}$ and 10.22 to $23.86 \mathrm{wt}^{2}$, respectively. The results indicate that the $\mathrm{CO}_{2}$ adsorption by the samples of calcium zirconate and alkalinity of samples of the calcium zirconate were increased with the increased in the mol ratio of $\mathrm{Ca} / \mathrm{Zr}$ in the samples of the calcium zirconate.

\section{6. $\mathrm{CO}_{2}$ adsorption at $600{ }^{\circ} \mathrm{C}$ by the sample of}

\section{calcium zirconate (solid-solid fusion method)}

In the Figure 8, the alkalinity of the samples of calcium zirconate with $\mathrm{Ca} / \mathrm{Zr}=0.5$ to $6 \mathrm{~mol}$ ratio and $\mathrm{CO}_{2}$ adsorption by the samples of calcium zirconate with $\mathrm{Ca} / \mathrm{Zr}=0.5$ to $6 \mathrm{~mol}$ ratio at $600{ }^{\circ} \mathrm{C}$ were shown. The alkalinity of samples of the calcium zirconate and $\mathrm{CO}_{2}$ adsorption by the samples of calcium zirconate with $\mathrm{Ca} / \mathrm{Zr}=0.5$ to 6 mol ratio were in the range from 0.06 to $8.4 \mathrm{mmol}$ $\mathrm{g}^{-1}$ and 11.12 to $23.32 \mathrm{wt}^{\%}$, respectively. The alkalinity of the samples of the calcium zirconate and $\mathrm{CO}_{2}$ adsorptions by the samples of the calcium zirconate at $600{ }^{\circ} \mathrm{C}$ were increased with the increased in the mol ratio of $\mathrm{Ca} / \mathrm{Zr}$ (0.5 to 6) in the samples of calcium zirconate.

\section{$3.7 \mathrm{CO}_{2}$ adsorption at $600{ }^{\circ} \mathrm{C}$ by the samples of the calcium zirconate (template method)}

The alkalinities of the samples of the calcium zirconate and $\mathrm{CO}_{2}$ adsorption by the samples of the calcium zirconate were $11.8,1.5$ and $1.2 \mathrm{mmol} \mathrm{g}^{-1}$ and $23.39,17.32$ and 15.92 wt \%, respectively (Figure 9). Where, the samples of the calcium zirconate were prepared by using of the template $\mathrm{CTAB}$ and the precursors $\mathrm{CaCO}_{3}, \mathrm{Ca}\left(\mathrm{NO}_{3}\right)_{2}$ and calcium acetate. In the process of preparation of samples of the calcium zirconate with $\mathrm{Ca} / \mathrm{Zr}=0.5$ to 6 mol ratios by using the template $\mathrm{CTAB}$ and precursors $\mathrm{Ca}\left(\mathrm{NO}_{3}\right)_{2}, \mathrm{CaCO}_{3}$ and calcium acetate, the $\mathrm{Ca}\left(\mathrm{NO}_{3}\right)_{2}$ and calcium acetate were relatively more soluble in aqueous solution in comparison with that of $\mathrm{CaCO}_{3}$. The results indicated that the alkalinity of the samples of the calcium zirconate and $\mathrm{CO}_{2}$ adsorption by the samples of the calcium zirconate at $600{ }^{\circ} \mathrm{C}$ was increased with the increased in the mol ratio of $\mathrm{Ca} / \mathrm{Zr}$ from 0.5 to 6 in the samples of calcium zirconate.

\section{8 $\mathrm{CO}_{2}$ adsorption at $600{ }^{\circ} \mathrm{C}$ by the samples of the calcium zirconate (micro emulsion method)}

In the Figure 10, the alkalinity of the samples of the calcium zirconate and $\mathrm{CO}_{2}$ adsorption by the samples of the calcium zirconate at $600{ }^{\circ} \mathrm{C}$ with

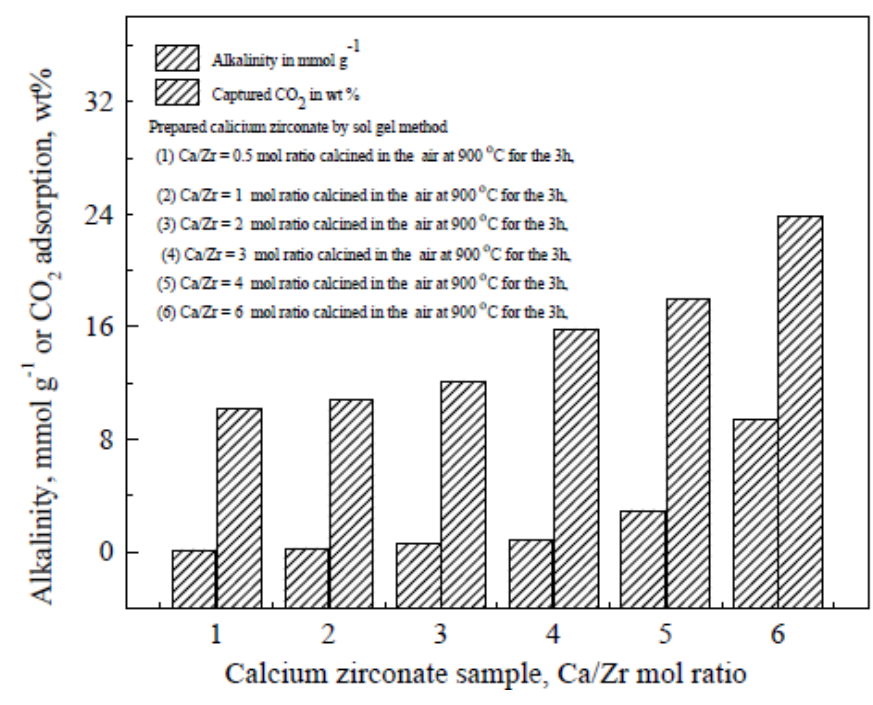

Figure 7. The plot of alkalinity of the samples of the calcium zirconate and $\mathrm{CO}_{2}$ adsorption by the samples of the calcium zirconate against the different $\mathrm{Ca} / \mathrm{Zr}$ mol ratios of the samples of the calcium zirconate where the samples of the calcium zirconate were prepared by the sol-gel method.

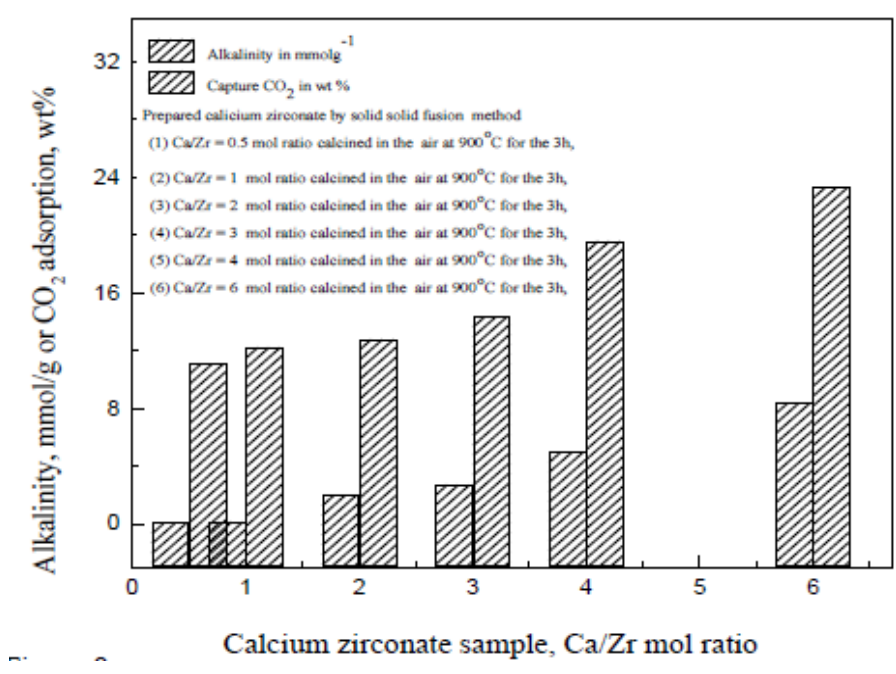

Figure 8. The plot of alkalinity of the samples of the calcium zirconate and $\mathrm{CO}_{2}$ adsorption by the samples of the calcium zirconate against the different $\mathrm{Ca} / \mathrm{Zr}$ mol ratios of the samples of the calcium zirconate where the samples of the calcium zirconate were prepared by the solid-solid fusion method. 


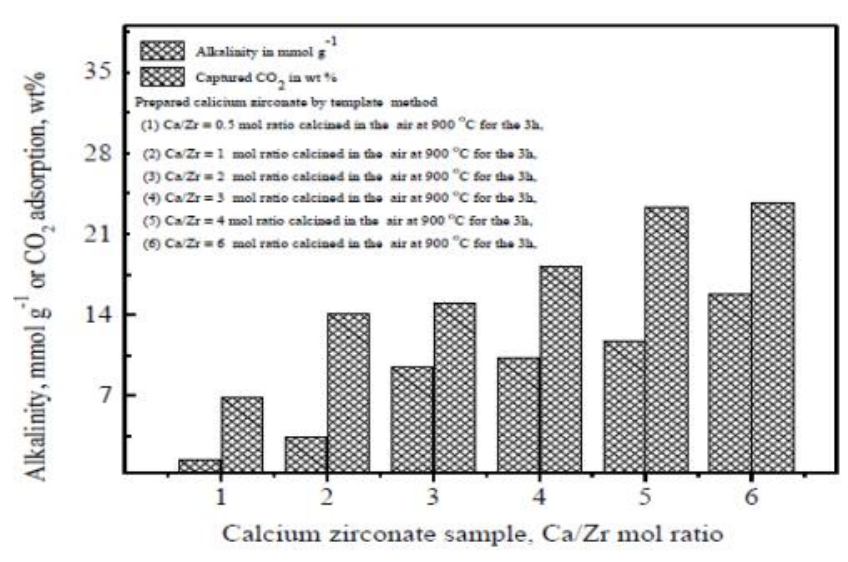

Figure 9. The plot of alkalinity of the samples of the calcium zirconate and $\mathrm{CO}_{2}$ adsorption by the samples of the calcium zirconate against the different $\mathrm{Ca} / \mathrm{Zr}$ mol ratios of the samples of the calcium zirconate where the samples of the calcium zirconate were prepared by the template method.

$\mathrm{Ca} / \mathrm{Zr}=0.5$ to $6 \mathrm{~mol}$ ratio were presented. The observed alkalinity of the samples of the calcium zirconate with $\mathrm{Ca} / \mathrm{Zr}=0.5$ to $6 \mathrm{~mol}$ ratio was in the range from 1.6 to $23.0 \mathrm{mmol} \mathrm{g}^{-1}$. However, the $\mathrm{CO}_{2}$ adsorption at $600{ }^{\circ} \mathrm{C}$ by the samples of the calcium zirconate with $\mathrm{Ca} / \mathrm{Zr}=0.5$ to $6 \mathrm{~mol}$ ratio was in the range from 12.1 to 27.01 wt \%. The results indicated that the alkalinities of the samples of the calcium zirconate and $\mathrm{CO}_{2}$ adsorption by the samples of the calcium zirconate were increased along with the increased in the $\mathrm{Ca} / \mathrm{Zr}$ mol ratio from 0.5 to 6 in the samples of the calcium zirconate.

The acidity/alkalinity of the samples of the calcium zirconate depends on the mol ratio of the $\mathrm{Ca} / \mathrm{Zr}$ in the samples of the calcium zirconate. The estimated alkalinity (Table 1) of the samples of the $\mathrm{CaO}$, acidity of the samples of the $\mathrm{SiO}_{2}$ and $\mathrm{ZrO}_{2}$ were 20, 1.1 and $0.56 \mathrm{mmol} \mathrm{g}^{-1}$, respectively. However, the $\mathrm{CO}_{2}$ adsorption by the samples of the $\mathrm{CaO}, \mathrm{SiO}_{2}$ and $\mathrm{ZrO}_{2}$ were $6.88,1.1$ and 8.39 wt \%, respectively. The $\mathrm{CO}_{2}$ adsorption by the samples of the $\mathrm{CaO}, \mathrm{SiO}_{2}$ and $\mathrm{ZrO}_{2}$ at $600{ }^{\circ} \mathrm{C}$ was in the agreement with the alkalinity and acidity of the samples of the $\mathrm{CaO}, \mathrm{SiO}_{2}$ and $\mathrm{ZrO}_{2}$. Moreover, the alkalinities of the samples of the calcium zirconate and $\mathrm{CO}_{2}$ adsorption by the samples of the calcium zirconate were in the order of increased $\mathrm{Ca} / \mathrm{Zr}$ mol ratio from 0.5 to 6 of in the samples of the calcium zirconate (Figures 7-10).

\subsection{Effect of promoters on $\mathrm{CO}_{2}$ adsorption}

To check the effect of promoters on the $\mathrm{CO}_{2}$ adsorption by the samples of the calcium zirconate at pre-combustion temperature, $2 \mathrm{wt} \%$ loadings of alkali metals $\left(\mathrm{K}^{+}, \mathrm{Na}^{+}, \mathrm{Rb}^{+}, \mathrm{Cs}^{+}\right.$, etc.), lanthanide

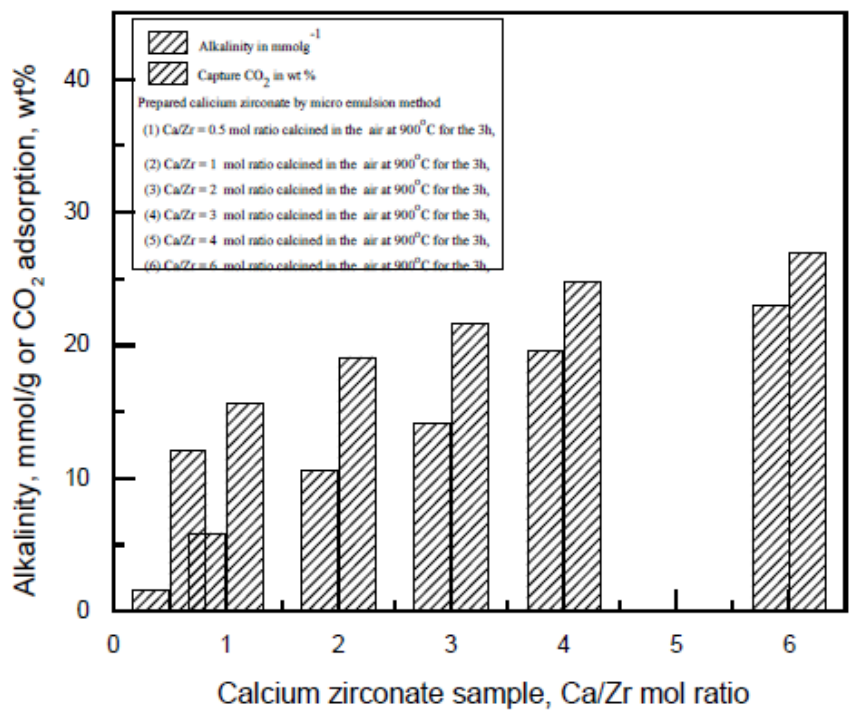

Figure 10. The plot of alkalinity of the samples of the calcium zirconate and $\mathrm{CO}_{2}$ adsorption by the samples of the calcium zirconate against the different $\mathrm{Ca} / \mathrm{Zr}$ mol ratio of the samples of the calcium zirconate where the samples of the calcium zirconate were prepared by micro emulsion method.

metal $\left(\mathrm{La}^{3+}\right)$, transition metal $\left(\mathrm{Ag}^{+}\right)$were done over the samples of the calcium zirconate. The promoted samples of the calcium zirconate were calcined at $900{ }^{\circ} \mathrm{C}$ for $3 \mathrm{~h}$. Table 2 shows the alkalinity of the samples of the calcium zirconate and $\mathrm{CO}_{2}$ adsorption by the promoted samples of the calcium zirconate. The $\mathrm{CO}_{2}$ adsorption by the promoted samples of the calcium zirconate by alkali metals showed the trend in the increased order of $\mathrm{Na}<\mathrm{K}$ $<\mathrm{Cs}<\mathrm{Rb}$. However, the promoter effects of $\mathrm{Ag}$ and $\mathrm{La}$ for the $\mathrm{CO}_{2}$ adsorption by the samples of the calcium zirconate were lower in comparison with that of the alkali metals promoted samples of the calcium zirconate.

3.10. The effect of exposure time on the adsorption of $\mathrm{CO}_{2}$ by the sample of the calcium zirconate

The sample of the calcium zirconate was prepared by the solid-solid fusion method by using the calcium carbonate and zirconyl nitrate. The sample of the calcium zirconate was calcined at $900{ }^{\circ} \mathrm{C}$ in helium atmosphere for $3 \mathrm{~h}$. In the Figure 11, the effect of exposure time of $\mathrm{CO}_{2}$ over the sample of the calcium zirconate for the $\mathrm{CO}_{2}$ adsorption was presented for the time until 120 min. The $\mathrm{CO}_{2}$ adsorption by the sample of the calcium zirconate was observed for the above period $40.5 \mathrm{wt} \%$. 


\subsection{The regenerability of calcium zirconate sample}

The regenerability of the sample of the calcium zirconate for $\mathrm{CO}_{2}$ adsorption was tested (Figure 12). The used sample of the calcium zirconate was prepared by the micro emulsion method and calcined in air with $\mathrm{Ca} / \mathrm{Zr}=4 \mathrm{~mol}$ ratio. The $\mathrm{CO}_{2}$ adsorption and de-sorption by the sample of calcium zirconate are the reactions of the formation of metal carbonate and decomposition of metal carbonate at higher temperature $>450{ }^{\circ} \mathrm{C}$, respectively. The metal carbonate formation is a solid-gas reaction between the metal oxide and $\mathrm{CO}_{2}$ gas. However, the metal carbonate decomposition (solid to gas and solid) is a solid reaction of formation of metal oxide and $\mathrm{CO}_{2}$. In addition to this, the solid-solid calcium oxide and zirconium oxides also react to each other to generate the solid crystalline phase of calcium zirconate.

Table 2. The alkalinity of the promoted the sample of calcium zirconate and the $\mathrm{CO}_{2}$ adsorption at $600^{\circ}$ $\mathrm{C}$ by the promoted the sample of calcium zirconate with $\mathrm{Ca} / \mathrm{Zr}=4 \mathrm{~mol}$ ratio (the promoted the samples of calcium zirconate were prepared by solid-solid fusion method)

\begin{tabular}{cccc}
\hline $\begin{array}{c}\text { Sr. } \\
\text { No }\end{array}$ & $\begin{array}{c}\text { Metal load- } \\
\text { ed, } \\
2 \mathrm{Wt} \%\end{array}$ & $\begin{array}{c}\text { Alkalini- } \\
\text { ty, } \\
\text { mmol- }^{-1}\end{array}$ & $\begin{array}{c}\mathrm{CO}_{2} \text { adsorp- } \\
\text { tion, } \\
\text { wt } \%\end{array}$ \\
\hline 1 & & 5.0 & 19.61 \\
2 & $\mathrm{Na}$ & 5.4 & 24.74 \\
3 & $\mathrm{~K}$ & 5.6 & 25.83 \\
4 & $\mathrm{Rb}$ & 7 & 29.53 \\
5 & $\mathrm{Cs}$ & 9.6 & 31.19 \\
6 & $\mathrm{La}$ & 5.2 & 24.46 \\
7 & $\mathrm{Ag}$ & 4.0 & 23.82 \\
\hline
\end{tabular}

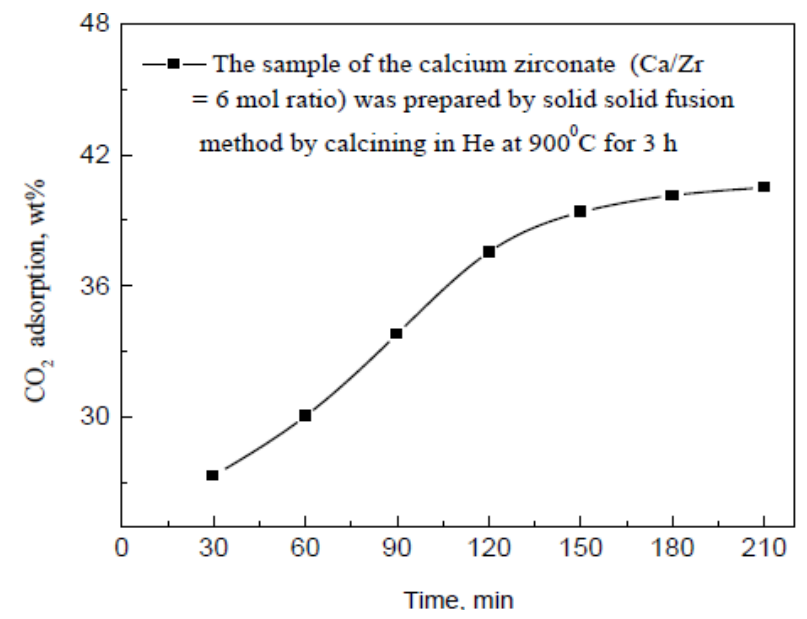

Figure 11. The effect of exposure time of $\mathrm{CO}_{2}$ over the samples of the calcium zirconate on the $\mathrm{CO}_{2}$ adsorption by the samples of the calcium zirconate.
Simultaneously, the three reactions parallel and continuously competitively occurring are the formation of calcium and zirconium carbonate, decomposition of calcium and zirconium carbonate and calcium zirconate crystalline phase reformation from calcium and zirconium mixed oxide. However, one of the reactions is certainly dominating at a certain temperature $>450{ }^{\circ} \mathrm{C}$. In order to check the regenerability of the sample of the calcium zirconate, a sample of the calcium zirconate was tested for 50 cycles at certain temperature repeatedly for the adsorption and desorption of $\mathrm{CO}_{2}$ at high and low temperatures. However, there was no change in the capacity of the sample of the calcium zirconate for adsorption and de-sorption of $\mathrm{CO}_{2}$ (Figure 12).

\section{Conclusion}

The several samples of the calcium zirconate were prepared by different methods such as sol gel, solid-solid fusion, template and micro-emulsion methods. The samples of the calcium zirconate were prepared by template and micro emulsion methods showed the higher $\mathrm{CO}_{2}$ adsorptions in comparison with that of the samples of the calcium zirconate were prepared by other methods. The increased alkalinities of the samples of the calcium zirconate and $\mathrm{CO}_{2}$ adsorption by the samples of the calcium zirconate were observed in the increased order of the mol ratio of $\mathrm{Ca} / \mathrm{Zr}$ from 0.5 to 6 in the samples of the calcium zirconate. The thermo gravimetric analysis of the samples of the calcium zirconate showed that the samples of the calcium zirconate adsorb the moisture which was the cause

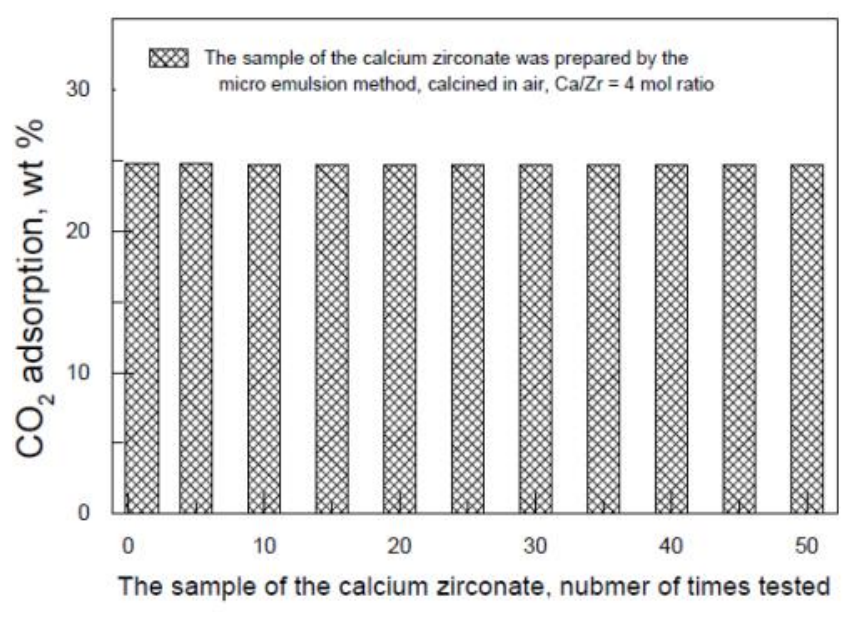

Figure 12 Regenerability of calcium zirconate, the sample of the calcium zirconate was prepared by the micro emulsion method and calcined in air with $\mathrm{Ca} / \mathrm{Zr}=4 \mathrm{~mol}$ ratio 
of loss in weight of the samples of the calcium zirconate. However, moisture in the samples of the calcium zirconate helps for the $\mathrm{CO}_{2}$ adsorption. The promoters like $\mathrm{K}^{+}, \mathrm{Na}^{+}, \mathrm{Rb}^{+}, \mathrm{Cs}^{+}, \mathrm{Ag}^{+}$and $\mathrm{La}^{3+}$ showed the increased $\mathrm{CO}_{2}$ adsorption by the samples of the calcium zirconate. The exposure time of $\mathrm{CO}_{2}$ on the $\mathrm{CO}_{2}$ adsorption by the samples of the calcium zirconate is also an important parameter. The regenerable and reusable samples of the calcium zirconate were found to be for the adsorption of $\mathrm{CO}_{2}$ at the post- and pre-combustion temperatures.

\section{Acknowledgement}

Authors are grateful to CSIR for the financial support for the net work project NWP0021.

\section{References}

[1] Hardie, S. M. L., Garneu, M. H., Rowland A. P., and Ostle, N. J. (2005). Carbon Dioxide Capture Using a Zeolite Molecular Sieves Sampling System for Isotopic Studies $\left({ }^{13} \mathrm{C}\right.$ and $\left.{ }^{14} \mathrm{C}\right)$ of Respiration. Radio Carbon, 43(3): 441-451.

[2] Lu, C., Bai, H., Wu, B., Su, F., and Wang, F. H. (2008). Comparative Study of $\mathrm{CO}_{2}$ Capture by Carbon Nano Tube, Activated Carbon and Zeolite. Energy and Fuels, 22: 3050-3056.

[3] Stolaroff, J. K., Lowry, G. V., and Keith, D. W. (2005). Using $\mathrm{CaO}$ and $\mathrm{MgO}$ Rich Industrial Waste Streams for Carbon Sequestration. Energy Conversion and Management, 46: 687-699.

[4] Jason, C. H., Jeffrey, H. D., Daniel, J. F., McMahan, L. G., Genggeng, Q., and Christopher, W. J. (2008). Designing Adsorbents for $\mathrm{CO}_{2}$ Capture from Flue Gas-Hyperbranched Aminosilicas Capable of Capturing $\mathrm{CO}_{2}$ Reversibly. Journal of the American Chemical Society, 130: 2902-2903.

[5] Chaikittisilp, W., Khunsupat, R., Chen, T. T., and Christopher, W. J. (2011). Poly (allylamine) (PAA) Mesoporous Silica Composite Materials for $\mathrm{CO}_{2}$ Capture from Simulated Flue Gas or Ambient Air. Industrial Engineering \& Chemistry Research. 50: 14203-14210.

[6] Liu, W., Feng, B., Wu, Y., Wang, G., Barry, J., and Da Costa, J. C. D. (2010). Synthesis of Sintering Resistance Sorbents for $\mathrm{CO}_{2}$ Capture. Environmental Science and Technology, 44: 30933097.

[7] Duan, Y., and Sorescu, D. C. (2010). $\mathrm{CO}_{2}$ Capture Properties of Alkaline Earth Metal Oxide and Hydroxides: A Combined Density Functional Theory and Lattice Phonon Dynamics Study. The Journal of Chemical Physics, 133: 074508.

[8] Yang, H., Xu, Z., Fan, M., Gupta, R., Slimane, R. B., Bland, A. E., and Wright I. (2008). Progress in
Carbon Dioxide Separation and Capture, a Review. Journal of Environmental Sciences, 20: 14-27.

[9] Kato, M., Maezawa, Y., Takeda, S., Hagiwara, Y., Kogo, R., Semba, K., and Hamamura, M. (2006). Pre-combustion $\mathrm{CO}_{2}$ Capture Using Ceramic Adsorbent and Methane Steam Reforming. Key Engineering Materials, 8: 317-318.

[10] Essaki, K., Kato, M., and Uemoto, H. (2005). Influence of Temperature and $\mathrm{CO}_{2}$ Concentration on the $\mathrm{CO}_{2}$ Adsorption Properties of Lithium Silicate Pellets. Journal of Material Science, 40: 5017-5019.

[11] Kato, M., Nagakawa, K., Essaki, K., Maezawa, Y., Takeda, S., Kago, R., and Hagiwara, Y. (2005). Novel $\mathrm{CO}_{2}$ Adsorbent Using Lithium Containing Oxide. International Journal of Applied Ceramic Technology, 2 (6): 467-475.

[12] Essaki, K., and Kato, M. (2006). Reproducibility of Lithium Silicate Pellets in $\mathrm{N}_{2}$ Atmosphere. Journal of Chemical Engineering of Japan, 39: 1167-1164.

[13] Li, L., King, D. L., Nie, Z., Li, X. S., and Howard, C. (2010). $\mathrm{MgAl}_{2} \mathrm{O}_{4}$ Spinel Stabilized Calcium Oxide Adsorbents with Improved Durability for High Temperature $\mathrm{CO}_{2}$ Capture. Energy and Fuel, 24: 6398-3703.

[14] Li, L., King, D. L., Nie, Z., Li, X. S., and Howard, C. (2009). Magnesia Stabilized Calcium Oxide Adsorbents with Improved Durability for High Temperature $\mathrm{CO}_{2}$ Capture. Industrial \& Engineering Chemistry Research, 48: 1060410613.

[15] Wang, X. P., Yu, J. J., Cheng, J., Hao, Z. P., and Yu, Z. P. (2008). High Temperature Adsorption of Carbon Dioxide on Mixed Oxides Derived from Hydrotalcite Like Compounds. Environmental Science \& Technology, 42: 614-618.

[16] Leon, M., Diaz, E., Bennici, S., Vega, A., Ordonez, S., and Auroux, A. (2010). Adsorption of $\mathrm{CO}_{2}$ on Hydrotalcite Derived Mixed Oxide Sorption Mechanisms and Consequences for Adsorption Irreversibility. Industrial \& Engineering Chemistry Research, 49: 3663-3671.

[17] Manovic, V., and Anthony, E. I. (2008). Thermal Activation of $\mathrm{CaO}$ - Based Sorbents and Self Activation During $\mathrm{CO}_{2}$ Capture Looping Cycles. Environmental Science \& Technology, 42: 14704174.

[18] Siriwardane, R. V., Robinson, C., Shen, M., and Simonyi, T., (2007). Novel Regenerable Sodium Based Sorbents for $\mathrm{CO}_{2}$ Capture at Warm Gas Temperatures. Energy and Fuel, 21: 2088-2097.

[19] Zafar, Q., Mattission, T., and Gevert, B. (2005). Integrated Hydrogen and Power Production with $\mathrm{CO}_{2}$ Capture Using Chemical Looping Reforming 
Redox Reactivity of Particles of $\mathrm{CaO}, \mathrm{MnO}_{3}, \mathrm{NiO}$ and $\mathrm{Fe}_{2} \mathrm{O}_{3}$ Using $\mathrm{SiO}_{2}$ as a Support. Industrial \& Engineering Chemistry Research, 44: 3485-3496.

[20] Li, Z., Cai, N., and Huang, Y. (2006). Effect of Preparation Temperature on Cyclic $\mathrm{CO}_{2}$ Capture and Multiple Carbonation- Calcination Cycles for a New Ca-based $\mathrm{CO}_{2}$ Sorbent. Industrial \& Engineering Chemistry Research, 42: 1911-1917.

[21] Yin, X., Li, S., Zang, Q., and Yu, J. (2010). Synthesis and $\mathrm{CO}_{2}$ Adsorption Characteristics of Lithium Zirconates with High Lithia Content. Journal of the American Ceramic Society, 93(9): 2837-2842,

[22] Lu, H., Khan, A., Pratsinis, S. E., and Smirniotis, P. G. (2009). Flame Made Durable Doped CaO Nano Sorbents for $\mathrm{CO}_{2}$ Capture. Energy and Fuel, 23: $1093-1100$.

[23] Koirala, R., Gunugunuri, K. R., Pratsinis, S. E., and Smirniotis, P. G. (2011). Effect of Zirconia Doping on the Structure and Stability of $\mathrm{CaO}$ Based Sorbents for $\mathrm{CO}_{2}$ Capture During Extended Operating Cycles. The Journal of Physical Chemistry, 115: 24804-24812.
[24] Choi, S., Drese, J. H., Eisenberger, P. M., and Jones C.W. (2011). Application of Amine Tethered Solid Sorbents for Direct $\mathrm{CO}_{2}$ Capture from the Ambient Air. Environmental Science \& Technology, 45: 2420-2427.

[25] Manovic, V., and Anthony, E. J. (2010). Lime Based Sorbents for High Temperature $\mathrm{CO}_{2}$ Capture- A Review of Sorbent Modification Methods. Internal Journal of Environmental Research and Public Health, 7: 3129-3140.

[26] Badaoui, A., Badaoui, M., and Kharchi, F. (2012). Carbonic Gas Randomness Effect on Reinforced Concrete. Carbonation Engineering, 4: 6- 10. 